\title{
Information and Communication Technologies as a Tool for Enhancing Meaningful and Sustainable Transnational Collaboration in Education
}

\author{
Sofowora Olaniyi Alaba(PhD) \\ Obafemi Awolowo University, Ile-Ife, Faculty of Education, Department of Education Technology, Ile-Ife, Osun State, Nigeria \\ oasofowora@oauife.edu.ng/oasofowora@yahoo.com/solaniyialaba@yahoo.com
}

\section{Doi:10.5901/mjss.2014.v5n23p1465}

\begin{abstract}
This paper discussed how Obafemi Awolowo University lle-Ife, Nigeria used ICTs as a tool for transnational collaboration. The issue of globalization and collaboration has implication for Nigeria as a country that is yet to provide qualitative education to its youths. The above neglect has been partly responsible for the recurrent insurgence among the youth in Nigeria especially Northern part (Boko-Haram) and in the South-South geopolitical zone (Niger Delta). As a result of frustration due to unemployment and education, these youths took to violence, thus becoming social menace. The University management employed ICTs to enhance transnational collaboration as a way to provide quality education through collaboration between universities using Distance Education.
\end{abstract}

Keywords: Globalization, New Emerging Technology, Transnational Education, Collaboration, Integrated Learning Management System, Open-Distance Learning

\section{Introduction}

Information and Communication Technologies (ICTS) is playing vital roles in the dissemination of knowledge and education. It also plays a paramount role in transforming the economic, social and the political life of the people. All over the world, because of the impact of ICTs in turning the world into a global village, there has been increase in international cooperation and collaboration. The integration of ICTs has also provided more access and opportunities for quality education across the frontiers of different nations at a global level through the process of "Transnational Education Transnational education is not new to us in Nigeria. It has been an age long phenomenon. What makes the difference today is its global expansion due to globalization. Today, the growth of transnational education brings with it increasing levels of competition between the educational institutions within and beyond the frontiers of countries. These astronomic growths in transnational education have implications for education in Nigeria. Prior to these era, Nigerian educational system with specific reference to higher education was characterized by many problems including, lack of access to quality higher education, inadequate academic staff, poor funding and inadequate infrastructures. The above have resulted in low admission of students into higher institutions in Nigeria. Thus, greater number of students who are qualified for admission could not be admitted due to inadequate facilities and poor infrastructures. Statistics has it that of the total 400,000 candidates seeking admission into Nigeria universities, $80 \%$ of them are unable to gain admission. According to an excerpt in Grandiose, quoted in "This Day" of 19th April (2006) only, 18.4\% of the 800,000 candidates that applied for admission were admitted. In 2003/2004, the percentage was 24\%; 2005/2006 academic session, 17\% got admission; 2006/2007 session, 8\%; and during 2007/2008 session, only 31\%. This problem has been age long and making the situation more worse is the high rate of youth unemployment. Statistics has it that about $80 \%$ of the Nigerian youths are unemployed. These explain the reasons why there are mass exodus of Nigerian youths to foreign universities in Britain, Asia, Europe or the United State of America for education.

The factors that were responsible for the low admission in Nigerian universities are not far fetched, they include: shortage of academic staff, and deplorable condition of facilities due to poor funding. Faborode (2008), commenting on the sordid state of universities, says: universities in Nigeria are in dare need of new push, vision and assurance. Also, according to the publication in Daily Independence (2006), there is need for Nigeria universities to change from being conventional source to becoming specialized institutions. It is against this background that transnational education and collaboration becomes necessary 


\section{Transnational Collaboration in Education}

The concept of collaboration and Transnational Education mean different things to different people depending on the culture and the stage of development. Cooks (1992) says these terms may lead to confusion. Also according to Hussein (2007), Aust, Furman and Quezada (2008), the use of the term is problematic as it does not currently have one clear definition. GATE (1997p.9) defines it as an export product that denotes any teaching or learning activity in which students are located in different countries to that in which the institutions providing the education is based. It requires that national boundaries be crossed by information about the education, staff and educational materials. According to Adam (1992), Transnational Education means all the different forms of educational programmes or set of courses at the tertiary level of education with specific reference to Distance Education. It involves learners located in different country where the courses operate. On the other hand, collaboration involves effective method of transferring "know how" or knowledge management for the purpose of creating and sustaining competitive market. It can also be viewed as a general cooperative agreement between two or more institutions of learning with the ultimate goal of working together to achieve a common objective. The ultimate goal of Transnational Education is to make higher education programme more accessible to interested and qualified candidates irrespective of their location. It is also designed to absorb large student enrolment for knowledge sharing beyond geographical boundaries through the new technologies.

Perhaps, it was based on this premise that Obafemi Awolowo University, lle-Ife in Nigeria decided to strengthen/enhance collaboration and cooperation across border in order to provide equitable and quality education not only to qualified Nigerians, but also to others across the geographical boundaries at a global level through transnational collaboration.

\subsection{Development of Transnational Collaboration in Education in Obafemi Awolowo University, Ile-lfe}

- In order to enhance collaboration, the University utilizes ICTs. Several projects were embarked upon between 2003 and 2010, funded by Carnegie Corporation of New York and the World Bank. It involved enhancing instruction using the new emerging technologies. According to Impact (2009), the first phase was aimed at strengthening and promoting gender equity. The objectives of this first phase according to impact (2009 p. 7) include Enhancing ICT capacity and application to Distance Learning;

- Computerization of the University Library;

- Computerization of the operations of the Bursary Department;

- Development of Computer Engineering Laboratory;

- Support for gender equity action plan of the University;

- Strengthening the office of linkages and partnership.

The second phase of the funding was in 2006, the following were the target objectives to be achieved:

- Integration of ICT potentials for teaching, learning, research and services;

- Promoting entrepreneurial resourcefulness of OAU graduates;

- Enhancing resourceful mobilization through linkages.

One of the activities of the collaboration with the Carnegie Corporation is the birth of the Directorate of Linkages and Sponsored Research. This led to the restructuring of the activities of the Committee on Relationship with Overseas Institutions. The new development and collaborative moves made the University to rebrand its programme and come out with new strategic plan. According to the official publication of OAU on Carnegie (2009), the University is to embark on the following:

- Develop a network of global partnerships and linkages;

- Develop a strong, community and national relationship;

- Promote staff exchange and greater student exchanges;

- Market academic and research activities;

- $\quad$ Regain the image of the university as an international institution.

Realizing the important role of ICTs in development and in education, OAU lle-lfe decided to harness the educational potentials of the internet and the new emerging technologies. The Information Technology Unit (INTECU) provided the university with the appropriate multi- media/modern technologies that provide support for the improvement of teaching, research and learning with emphasis on Open-Distance Education. This is with a view to providing more access to quality education to those that cannot come in for full time residential courses.

To ensure the success of this project, the university has to upgrade its bandwidth for VSAT, making use of high speed intra-web communication. Since these projects require a strong remote collaboration between all the teams, E-mail 
instant messaging remains the most pervasive team-based communication tool. This made the university to introduce optic fibre network. Other means of communication is the OAU Great FM 94.5(a digital radio station) and a new television station on Channel 45Uhf. In addition to obtaining a broadcast license, the university planned for a complete Integrated Learning Management System (ILMS) that has capabilities for real-time online synchronous funding between the students and their lecturers. The system is to encourage collaborative usage that is designed to enhance learning, class discussions, chatting and assignment. The University decided to use Integrated Learning Management System and blended learning to resolve the problems of large class teaching, problem of space facilities and for improving teaching and learning of Science/Technology related courses.

The Carnegie Corporation's collaborative project also supported other wide range of educational activities involving Library Computerization and digitalization. According to Impact (2006 p. 13), the Carnegie-funded project embarked upon networking the Library cataloguing system with the World cat of the Online Computer Library Center Inc. It also embarked on capacity building through staff training to manage the digitalization processes. The adoption, development, testing, implementation and dissemination of information on new methodologies and modern approaches using the new emerging technologies made the university the best and foremost ICT University in Nigeria. It was this that also won the university a new project called STEP-B improving Science and Technology Education in Post Basic Institutions of Learning. The objective of this project is to help produce more and better qualified Science and Technology graduates at the post basic level. It was also established to produce higher quality and more relevant research. According to the official news bulletin of STEP-B, the benefits are four folds:

(i) increases in the number of students trained in Science and Technology;

(ii) improving the quality of research studies and publications through better and effective national, transnational collaborations;

(iii) demystifying the teaching and learning of Science and Technology so as to motivate and encourage more students to study them; and

(iv) entrepreneurial education to help reduce youth/ graduate unemployment.

\section{Course Development}

One of the main activities embarked upon in this project is the development of ICT facilities for e-learning, training and course development. In order to enhance this, decisions were made about the partners to participate; the type of course; whether all courses or some selected courses; what course structure to adopt and the development strategies. However, it was decided that the university should use collaboration and committee system. There were collaboration between universities of Jos, Port Harcourt, Ibadan, Bowen University, Iwo, Backcock University, llishan in Ogun State and Adeyemi College of Education Ondo. Not only this, secondary school like International School, OAU, lle-lfe formed part of the collaborations. On the international scene, collaborations were made with Makerere University in Uganda; InterUniversity Council of East Africa, Kenya; Virtual University Kenya; University of the Witwaters, South Africa; Winneba University of Education in Ghana; and Massachusetts Institute of Technology, Boston and Liberia. OAU Ile-Ife played leadership role in collaborating with these institutions with the ultimate view of ensuring that the new Strategic Development Goals as stated in both the STEP-B and Carnegie's projects are achieved. The university employed team work that involves all the stake holders within and among the collaborating institutions. Team work was employed because of the belief that it is faster, more reliable, cost saving and of better quality. Not only this, since all stake holders are involved, its acceptability is not in doubt because personal biases have been removed and all have actively participated. The technology platform employed includes the new social technologies, multi-site teaching and ICT for elearning. The platforms include:

- Web aided radio and television broadcast;

- Integrated Learning Management System, Academic Blackboard;

- Course Modules;

- Internship trainings/field work for entrepreneurship programme.

\subsection{Training}

This is another essential component of the projects which is aimed at equipping the end user and the technical staff to acquire the needed skills in ICTs. End users and trainees are expected to train students, lecturers, professors, course cocoordinators, registry personnel, etc. on the use of the software while the technical training focuses on the technical aspects of the Learning Management software. This is with the view to modifying or adding capabilities that will enhance 
effective and efficient utilization. A number of training programmes were embarked upon. They include a collaborative leadership workshop on Web-Based Co-curriculum Development that was jointly organized by the Centre for Distance Learning and Department of Educational Technology where Paul Bateman and Pearl Robinson of the Tuft University were the resource persons. There were several other training workshops on:

(i) Designing and production of text materials for Distance Learning;

(ii) Open Distance and E-learning (ODEL).

These workshops were designed to discuss the delivery method, the design, commencement and transmission of the courses to the target group using open-distance Learning (ODEL) approach. It also involves the delivering mode and how the target audience will attend to course. Other discussions involve feedback mechanism (in terms of tasks, comments, questions, evaluation, grading and quality assurance procedures.

The university made use of a dedicated e-learning platform with the support of web collaboration platform that provides file and space sharing, synchronous and a synchronous accommodation like blogs, forum and chart rooms. With the provision of web-based facilities, multi- media centers at different locations on the campus for the students and the university mandatory ICT skill acquisition for all the academic/administrative staff and subsequent attempt at providing lap-tops,/desk top computers for staff at a highly subsidized price, the university was able to integrate ICT as a tool for effective move to providing knowledge, training and empowerment through Distance Education platform.

\section{The Benefits of Transnational Collaboration to OAU lle-lfe}

The benefits of transnational collaboration are multi-faceted. The impact of the programmes is felt on the students, the university, the staff and on the collaborating institutions. First, on the students from all the participating institutions, there was the promotion and new understanding of the role of ICTs in development, increased technical ICT skill, opening of bilateral cooperation and communication lines with other educational systems. Students' views and perspectives were broadened, there was increased in classroom motivation and excitement to learn. In O.A.U. Ile-Ife, there was a reduction in failure and drop-out rates. So also was improvement in education standard. There was also increase enrolment into Technology and Science related course. On the university itself, the rebranding led to the promotion of new creative curricula in all the departments. The collaboration and the rebranding led to improvement in the standard of education and the image of the University. Presently, the University has been able to establish a viable and effective Distance Education programme in almost all the courses. The courses range from Diploma to first degree and post graduate courses. There are over eight thousand candidates on this programme. As a result of the challenges in the country, the University uses web-based learning, e-mail integrated, threaded discussion forum, instant messaging, chart rooms, blogs and face-to-face meetings. Other tools used include variety of HTML image like images, video, audio and other multimedia in addition to digital television and radio lectures. The University had also carried out several research studies on the improvement of Science and Technology Teaching. Several scholarships were given to deserving and qualified female students to study Science and Technology related courses. Thus, as a result of this success story, the University was nominated as the foremost and leading ICT University in Nigeria, Centre of Excellence on STEP-B by the World Bank rating, and was able to make impact as a global cultural center and in the development of Open Distance Learning. The financial status of the University has greatly improved as a result of the collaborations sponsorship and the expansion of the Distance Learning Programme. It also made contributive development to Community Oral Health Programme through the Institute of Public Health, a programme which was the first of its kind in sub-Saharan Africa. Other significant contributions in the field of Transnational Education and Collaboration are:

- Space Science Education Collaborated by African Regional Centre for Space Science and Technology Education in English (ARCSSTE-E);

- Aerospace Education by Regional Centre for Training in Aerospace Surveys (RECTAS);

- Technology Management - National Centre for Technology Management (NACETEM);

- Research Collaboration and Development by the Directorate of Linkages and Sponsored Research Management; and

- Gender Studies by Centre for Gender Studies and Social Policy.

\section{Summary and Conclusion}

There is no denial of the fact that the new emerging technologies are effective tools for collaboration and national development. When the use of Information and Communication Technologies is combined with transnational collaboration in education, some of the challenges facing the educational system and the country might be resolved. This 
was the case of the University's effort at helping the deprived youths to acquire qualitative higher education through the Open Distance Learning approach in a depressed economy through the Open Distance Learning approach using ICTs and International Collaboration in Education as a backbone. The University was able to empower the Nigerian youths. It also provided life long learning, training and quality education through entrepreneurial empowerment programmes to the less disadvataged youths across the borders of Nigeria. For other categories of students, there were better and more viable courses for them to offer, the new innovation using the modern open distance learning approach led to change in students attitude, better understanding of cultures and values of other students in other part of the world. The students became life long learners, equipped with the skills to adapt to change, and were better prepared for their future careers. The funding status and the image of the university were improved. The same is applicable to management and administration of staff and students records. Other benefits include bridging the gender gap in the employment of academic staff. Postgraduate research was done with better equipment, better capacity building for secondary school and the staff of the collaborating institutions, especially with regards to Science and Technology related courses. The University has also successfully commenced Enterpreneuship Education at the secondary schools using OAU International Secondary School and OAU Staff School (Primary) as pilot study. With the above, it appears that Obafemi Awolowo University, Ile-Ife is taking the lead in Nigeria by using modern ICTs in teaching and to resolve some of the challenges facing higher education using Transnational Collaboration and Distance Education.

\section{References}

Adam, L. Cessna, K. Stein, P. and Friends M. (1992). Teachers and Co-teaching Qualitative Study of Experienced Co-teacher: An Unpublished Manuscript, Colorado Department of Education.

Andrea, M. and Weber, K. (2004). Effective Collaboration and Resource Sharing Among Graduate Programmes Educcause 2004, South East Regional Conference Atlanta.

Aust, R. Furman, R. and Quezada, C. (2008). Transnational Educational Technology. Proceedings of World ACS. LRN Guate Malu City. Guatemala.

Cooks, L. and Friends, M. (1990). Collaboration as a Predictor for Success in School Reform. Journal of Educational and Psychological Consultation 1(1), 69-90

Faborode, (2009). Welcome to Obafemi Awolowo University, Ile-Ife, Nigeria's Leading ICT University Published by the Office of the ViceChancellor, OAU, lle-lfe.

International Higher Education. Winter Edited Retrieved from the Internet http://www.bc.edu/bc.org/aup/soe/uhe/newsletter/Neosio/text 7.html.

Global Alliance for Transnational Education (GATE 1997) Certification Manual. Gate.

Hussein, I. (2007). Transnational Education: Concepts and Method. Juridical Online Journal of Distance Education 4 (1) Article 13.

Obafemi Awolowo University (2009) Impact! The Carnegie Corporation at Obafemi Awolowo University, Ile-Ife Vice-Chancellors Office, O.A.U. Ile-Ife.

Loveland, T. Miyakawu, H. and Hrayama, Y. (2004). International Collaboration in Secondary Level Education. Journal of Technology Studies, 30 (3), 10-19.

McBurnie, G. and Pollock, A. (1998). Transnational Education. An Australian Example.

Sofowora O.A. (2011). Impact of Globalization, Educational Branding and Innovative Technology on Development, Management and Quality Education in a Nigerian University International Journal and New Trends in Education and their Implications 2, (20, 78-88.

Suduc, A.M. and Bizor, M. (2011). Using Information and Communication Technologies to Support Collaboration with Multinational Education and Support. Proceedings of the Romanian Academy, Series A 12 (2), 159-164. 